\title{
Analysis of sewage sludge ashes from air and oxy-fuel combustion in a circulating fluidized-bed
}

\author{
Aneta Magdziarz ${ }^{\mathrm{a}}$, Monika Kosowska-Golachowska², Agnieszka Kijo-Kleczkowska², Katarzyna Środa², Krzysztof Wolski ${ }^{2}$, \\ Damian Richter ${ }^{2}$ and Tomasz Musiał ${ }^{2}$ \\ ${ }^{1}$ A GH University of Science and Technology, Mickiewicza 30 Av., 30-056 Krakow, Poland \\ ${ }^{2}$ Czestochowa University of Technology, Institute of Thermal Machinery, Armii Krajowej 21,42-201 Czestochowa, Poland
}

\begin{abstract}
The ashes from sewage sludge combustion in air versus $\mathrm{O}_{2} / \mathrm{CO}_{2}$ atmospheres with oxygen concentrations in the range of $21-40 \%$ vol. at temperature of $850^{\circ} \mathrm{C}$ in a $12 \mathrm{~kW}$ bench-scale CFB combustor were characterised. The chemical and phase composition of ashes were studied by XRF and XRD. The morphology of studied ashes were examined by SEM method. The slagging and fouling indices were calculated to study the deposition tendencies of ash. The thermal behaviour of ashes was studied by TG-DSC techniques, focusing on the mass loss and thermic effects with the increasing of temperature up to $1200^{\circ} \mathrm{C}$.
\end{abstract}

\section{Introduction}

Recently, increasing sewage sludge production and disposal, as well as the properties of sewage sludge, have been currently affecting the environment, which has resulted in legislation changes in Poland. Based on the Economy Minister Regulation of 16 July 2015 regarding the criteria and procedures for releasing wastes for landfilling, the thermal disposal of sewage sludge is important due to its gross calorific value, which is greater than $6 \mathrm{MJ} / \mathrm{kg}$, and the problems that result from its use and application. Consequently, an increasingly restrictive legislation that began on 1 January 2016 was introduced for sewage sludge storage in Poland. Sewage sludge incineration is an attractive option because it minimizes odour, significantly reduces the volume of the starting material and thermally destroys the organic and toxic components of the off pads. Currently, as many as 11 plants use sewage sludge as fuel in Poland; thus, this technology must be further developed in Poland while considering the benefits of co-combustion with other fuels.

There are several thermal technologies for utilising municipal sewage sludge to obtain useful forms of energy, such as pyrolysis, gasification, combustion, and co-combustion processes [1,2]. The combustion processes of sewage sludge and its combustion in relation to coal and biomass fuels and co-combustion are presented in [3-6].

Circulating fluidized bed (CFB) combustion has been considered as a common technology for waste sewage sludge due to the fuel-like characteristics of sewage sludge composed of lots of organic components. The capacity of commercial fluidized bed combustion plants ranged from 100 to 200 tons of waste sewage sludge per day. Those plants have utilized excess air for combustion, and have generated lots of carbon dioxide [7]. Oxy-fuel combustion is one of the leading technologies considered for capturing $\mathrm{CO}_{2}$ from power plants with CCS. This technology can significantly reduce emissions of $\mathrm{NO}_{\mathrm{x}}$ and improve the thermal efficiency of the combustion process by reducing the flue gas volume. In the oxy-fuel combustion, the fuel is burnt in a mixture of pure oxygen and recycled flue gas. Because $\mathrm{N}_{2}$ is eliminated from the oxidizing gas, the flue gas that leaves the combustion chamber is highly enriched in $\mathrm{CO}_{2}$ which means that the combustion process takes place in an $\mathrm{O}_{2} / \mathrm{CO}_{2}$ environment [8].

Sewage sludge is characterized by high moisture and ash contents, a low calorific value and the content of significant concentrations of substances that are environmentally unfriendly [9]. It should be noted that sewage sludge contains microorganisms and harmful substances including heavy metals, poorly biodegradable organic compounds, bacteria, viruses, pharmaceuticals, hormones and dioxins. The combustion of sewage sludge can cause operating problems because of the high moisture content, which is a significant and important issue regarding combustion and a large amount of ash. Additionally, gaseous pollutants $\left(\mathrm{CO}, \mathrm{C}_{\mathrm{x}} \mathrm{H}_{\mathrm{y}}, \mathrm{NO}_{\mathrm{x}}, \mathrm{SO}_{\mathrm{x}}\right.$, PAHs, dioxins and furans) and particular matters are generated [10].

However, despite the fact that technology concerning sewage sludge combustion has been developing well, new problems have appeared. They concern the amount and properties of ash. Burning sewage sludge generates a large amount of ash containing varied mineral compounds (even more than $30 \%$ ). The main elements

\footnotetext{
a Corresponding author: amagdzia@agh.edu.pl
} 
in the sewage sludge ash are silicon, phosphorus, calcium, magnesium, sulphur, potassium, chlorine and sodium. The amount and the chemical composition of ash can cause some risks during thermal conversion processes. The most important of them are slagging, bed agglomeration, fouling, and corrosion of the combustion devices, which degrade their performance and severely damage the firing equipment. The intensity of these phenomena depends on the chemical character of the ash, boiler design and operating conditions $[11,12]$. The most aggressive compounds of ash are alkali metals associated with sulphur and chlorine, which can form an agglomerated bed particles deposited on the metal surface limiting heat transfer and accelerating the corrosion process. Different correlations and methodologies have been used for predicting the slagging and fouling tendencies of solid fuel ashes. There are some empirical indices for predicting the slagging and fouling tendencies of ash correlating the chemical composition of ash. Most of them have been used for coal as well as biomass ashes [13-15] but Wang [16] used it for sewage sludge ashes.

The major objective of the paper is to present detailed characteristics of ashes obtained from air and oxy-fuel combustion in a circulating fluidized-bed. The aim of this paper was to study the influence of the combustion atmosphere on the chemical composition of the ash.

\section{Experimental}

\subsubsection{CFB combustor}

Air and oxy-fuel combustion tests were conducted in a 12-kW bench-scale CFB combustor shown schematically in Figure 1. The facility consists of a combustion chamber (1), a cyclone (2), a downcomer (3) and a loop seal (4). The electrically-heated rectangular combustion chamber (riser), $680 \times 75 \times 35 \mathrm{~mm}$, is the main component of the unit. Silica sand (particles smaller than $400 \mu \mathrm{m}$ ) to a mass of $0.3 \mathrm{~kg}$ constituted the inert bed. The gases that make up gas mixtures are supplied from cylinders (12) to a mixer (17) and then transferred via a preheater (8) directly into the combustion chamber. The flow rates of gases are controlled by valves (16) and measured by rotameters (15). During combustion tests, the superficial gas velocity was kept at a constant level of about $5 \mathrm{~m} / \mathrm{s}$. The temperature was held at $850^{\circ} \mathrm{C}$ by means of a microprocessor controller (11). S-type thermocouples (T1-T3) measured the temperature at three different levels inside the combustion chamber with an accuracy of $\pm 2^{\circ} \mathrm{C}$.

\subsubsection{Experimental procedures}

Once the fluidized bed had reached $850^{\circ} \mathrm{C}$, a $2 \mathrm{~g}$ sewage sludge sample was introduced to the riser and kept there for a period of time that corresponded to the time required for the complete combustion. The experiments were performed in air (base case) and mixtures of $\mathrm{O}_{2} / \mathrm{CO}_{2}$ with oxygen concentrations in a range from $21 \%$ to $40 \%$ vol.

Sewage sludge samples in the form of spherical granules from a sewage treatment plant serving large urban-industrial agglomeration in Poland were used in this study. The proximate and ultimate analyses of the tested sewage sludge are presented in Table 1.

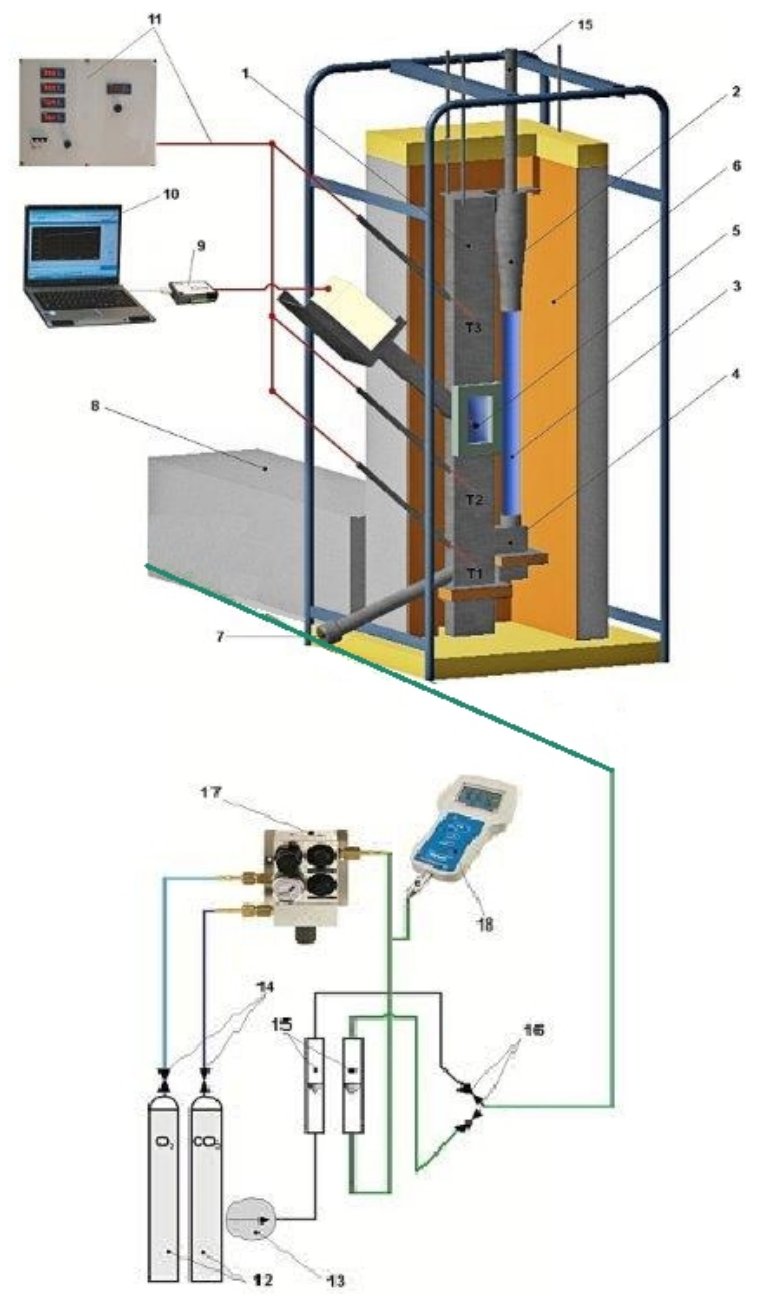

Figure 1. Schematic diagram of the experimental apparatus [8] 1-combustion chamber, 2-cyclone, 3-downcomer, 4-loop seal, 5-biomass particle, 6-insulation, 7-drain valve, 8-preheater, 9card, 10-computer, 11-temperature control system, 12-gas cylinders, 13-air compressor, 14-pressure regulators, 15rotameters, 16-valves, 17-mixer, 18-gas analyser, 19-ventilation duct, T1-T3-S-type thermocouples

For this study, four sewage sludge ashes were obtained from air and oxy-fuel combustion experiments. The samples were denoted as follows:

- Ash_1 - air (base case),

- Ash_2 - 21\% $\mathrm{O}_{2} / 79 \% \mathrm{CO}_{2}$,

- Ash_3 - 30\% $\mathrm{O}_{2} / 70 \% \mathrm{CO}_{2}$,

- Ash_ $4-40 \% \mathrm{O}_{2} / 60 \% \mathrm{CO}_{2}$.

The most important parameter determining the character of the ash is the chemical composition. The X-ray fluorescence (XRF, Riau ZSX Primus II) has been used to determine the main chemical composition of sewage sludge ashes (expressed 
in the form of oxides in Table 2). There were two kinds of oxides then the chemical properties were taken into account. The basic oxides are $\mathrm{Na}_{2} \mathrm{O}, \mathrm{K}_{2} \mathrm{O}, \mathrm{MgO}, \mathrm{CaO}$ and $\mathrm{Fe}_{2} \mathrm{O}_{3}$, and the acid oxides are $\mathrm{SiO}_{2}, \mathrm{Al}_{2} \mathrm{O}_{3}$ and $\mathrm{TiO}_{2}$.

The phase analysis of the sewage sludge ash was examined by X-ray diffraction (XRD) using PANanalytical EMPYREAN DY 1061 with $\mathrm{Cu} \mathrm{K} \alpha$ radiation in Bragg-Brentano geometry. The operating conditions of the XRD were $40 \mathrm{KV}$ and $40 \mathrm{~mA} \mathrm{Cu}$ $\mathrm{K} \alpha(\lambda=1.54 \AA)$ radiation and step-scanned in the range $2 \theta$ $=10-90^{\circ}$, step $0.06^{\circ}$, time $10 \mathrm{~s}$. For phase identification, a data base PDF-4+ product of ICDD was used.

A scanning Electron Microscopy with Energy Dispersive Spectroscopy (SEM-EDX) was applied to perform microanalysis of the ashes. The FEI Quanta 3D FEG Dual Beam microscope apparatus was used. Particles of the studied ashes were mounted on metal stubs by double sided carbon adhesive discs. The samples were observed in a high vacuum mode by secondary electrons (SEM) using the accelerating voltage - $1 \mathrm{kV}$.

TG-DSC technique (Thermogravimetry and Differential Scanning Calorimetry) was conducted using Netzsch STA 449 F3 Jupiter. The samples were heated in alumina crucibles from ambient temperature to $1200^{\circ} \mathrm{C}$ at a constant rate of $10^{\circ} \mathrm{C} / \mathrm{min}$ and at a 40 $\mathrm{ml} / \mathrm{min}$ flow of air.

Table 1. Proximate and ultimate analyses of the tested sewage sludge (dry basis) [1]

\begin{tabular}{|c|c|}
\hline \multicolumn{2}{|c|}{ Proximate analysis } \\
\hline Moisture, wt.\% & 4.9 \\
\hline Volatiles matter, wt.\% $\%$ & 51.4 \\
\hline Ash,wt.\% & 36.4 \\
\hline Fixed carbon, wt.\% & 45.6 \\
\hline Higher heating value, MJ/kg & 12.57 \\
\hline \multicolumn{2}{|c|}{ Ultimate analysis } \\
\hline Carbon, wt.\% & 30.8 \\
\hline Hydrogen, wt.\% & 3.9 \\
\hline Nitrogen, wt.\% & 4.3 \\
\hline Sulphur, wt.\% & 1.4 \\
\hline Oxygen (by difference), wt.\% & 18.3 \\
\hline
\end{tabular}

The presented proximate and ultimate analyses of the studied sewage sludge responded as typical sewage sludge. The volatile matter of $51.4 \mathrm{wt}$ \% corresponds to a higher heating value of $45.6 \mathrm{MJ} / \mathrm{kg}$. The sludge contains very high amount of ash, $36.4 \%$. The carbon content of $30.8 \%$ is an average value for this kind of renewable fuels. The moisture content is low, at $4.9 \%$, because the sample followed the drying process. Normally, raw sewage sludge has a moisture content of approximately $90 \%$. The $\mathrm{H}, \mathrm{N}$ and $\mathrm{S}$ contents are comparable to other studied sewage sludge samples $[2,6]$. The presented sewage sludge has "good fuel properties" and can be successfully used as a fuel for the combustion process.

\section{Results and discussion}

The content of the major inorganic elements in the investigated ashes in the form of oxides is given in Table 2. The main compounds of the ashes are $\mathrm{SiO}_{2}$, $\mathrm{Fe}_{2} \mathrm{O}_{3}, \mathrm{P}_{2} \mathrm{O}_{5}, \mathrm{CaO}, \mathrm{Al}_{2} \mathrm{O}_{3}, \mathrm{MgO}, \mathrm{TiO}_{2}, \mathrm{~K}_{2} \mathrm{O}, \mathrm{Na}_{2} \mathrm{O}$ and $\mathrm{SO}_{3}$. Sewage sludge contains high amounts of phosphorus, calcium and iron as well as silicon.

Table 2. Ash composition expressed as oxides, wt. \% (XRF method)

\begin{tabular}{|c|c|c|c|c|}
\hline & Ash_1 & Ash_2 & Ash_3 & Ash_4 \\
\hline $\mathrm{SiO}_{2}$ & 26.83 & 28.05 & 27.48 & 28.29 \\
\hline $\mathrm{Al}_{2} \mathrm{O}_{3}$ & 7.13 & 6.95 & 7.01 & 6.89 \\
\hline $\mathrm{Fe}_{2} \mathrm{O}_{3}$ & 20.63 & 20.03 & 19.95 & 20.21 \\
\hline $\mathrm{TiO}_{2}$ & 1.05 & 0.94 & 0.99 & 0.93 \\
\hline $\mathrm{CaO}$ & 18.12 & 17.55 & 17.88 & 17.56 \\
\hline $\mathrm{Na}_{2} \mathrm{O}$ & 0.39 & 0.38 & 0.39 & 0.36 \\
\hline $\mathrm{K}_{2} \mathrm{O}$ & 0.83 & 0.79 & 0.80 & 0.81 \\
\hline $\mathrm{MgO}$ & 2.46 & 2.35 & 2.44 & 2.32 \\
\hline $\mathrm{Cr}_{2} \mathrm{O}_{3}$ & 0.18 & 0.17 & 0.17 & 0.19 \\
\hline $\mathrm{CuO}$ & 0.12 & 0.12 & 0.11 & 0.11 \\
\hline $\mathrm{ZnO}$ & 0.75 & 0.76 & 0.77 & 0.77 \\
\hline $\mathrm{P}_{2} \mathrm{O}_{5}$ & 18.82 & 18.31 & 18.58 & 18.27 \\
\hline $\mathrm{SO}_{3}$ & 2.11 & 2.96 & 2.80 & 2.63 \\
\hline $\mathrm{Cl}$ & 0.01 & 0.03 & 0.02 & 0.02 \\
\hline$R_{B}$ & 42.43 & 41.10 & 41.46 & 41.26 \\
\hline$R_{B / A}$ & 1.21 & 1.14 & 1.17 & 1.14 \\
\hline$R_{B / A+P}$ & 1.75 & 1.65 & 1.69 & 1.65 \\
\hline$S_{R}$ & 39.43 & 41.26 & 40.56 & 41.37 \\
\hline$R_{S}$ & 1.69 & 1.60 & 1.64 & 1.60 \\
\hline$F_{u}$ & 1.48 & 1.33 & 1.39 & 1.33 \\
\hline $\mathrm{Fe}_{2} \mathrm{O}_{3} / \mathrm{CaO}$ & 1.14 & 1.14 & 1.12 & 1.15 \\
\hline
\end{tabular}


The concentrations of $\mathrm{K}$ and $\mathrm{Na}$ are low. The ashes were obtained in different combustion conditions (atmospheres), but the chemical composition and concentration of elements for all of the studied ashes are quite similar.

Minor differences have been observed between ashes obtained under air and oxy-combustion atmospheres. It suggests that combustion conditions do not significantly influence the chemical composition of ash.

The amount of ash is a serious problem in the combustion process of sewage sludge because of the high risk of slagging, bed agglomeration, fouling, and corrosion in the combustion devices. The presence of ash deposit material reduces the heat transfer and combustion efficiency, and damages combustion chambers when large particles break off. There are some empirical indices correlating the functional temperature and standardized chemical composition of ashes, thus making it possible to predict the ash behaviour and deposition tendencies [13-16] $\left(R_{B}-\right.$ sum of percentage of basic components, $R_{B / A}$ - ratio of basic to acidic components in ash, $R_{B / A+P}$ - ratio of basic to acidic components with considering phosphorus in ash, $S_{R}$ - viscosity index, $R_{S}$ - slagging index where $S^{d}$ is the percentage of $\mathrm{S}$ in dry fuel, $F_{u}$ - fouling index):

$$
\begin{aligned}
& R_{B}=\left(\mathrm{Fe}_{2} \mathrm{O}_{3}+\mathrm{CaO}+\mathrm{MgO}+\mathrm{Na}_{2} \mathrm{O}+\mathrm{K}_{2} \mathrm{O}\right) \\
& R_{\mathrm{B} / \mathrm{A}}=\left(\mathrm{Fe}_{2} \mathrm{O}_{3}+\mathrm{CaO}+\mathrm{MgO}+\mathrm{Na}_{2} \mathrm{O}+\mathrm{K}_{2} \mathrm{O}\right) / \\
& \left(\mathrm{SiO}_{2}+\mathrm{Al}_{2} \mathrm{O}_{3}+\mathrm{TiO}_{2}\right) \\
& R_{\mathrm{B} / \mathrm{A}+\mathrm{P}}=\left(\mathrm{Fe}_{2} \mathrm{O}_{3}+\mathrm{CaO}+\mathrm{MgO}+\mathrm{Na}_{2} \mathrm{O}+\mathrm{K}_{2} \mathrm{O}+\mathrm{P}_{2} \mathrm{O}_{5}\right) / \\
& \left(\mathrm{SiO}_{2}+\mathrm{Al}_{2} \mathrm{O}_{3}+\mathrm{TiO}_{2}\right) \\
& S_{R}=100 \mathrm{SiO}_{2} /\left[\mathrm{SiO}_{2}+e q\left(\mathrm{Fe}_{2} \mathrm{O}_{3}\right)+\mathrm{CaO}+\mathrm{MgO}\right] \\
& R_{S}=R_{B / A} S^{d} \\
& F_{u}=R_{B / A}\left(\mathrm{Na}_{2} \mathrm{O}+\mathrm{K}_{2} \mathrm{O}\right)
\end{aligned}
$$

The slagging tendency depends on $R_{S}$ value and if $R_{S}$ $<0.6$ - low slagging inclination $R_{S}=0.6 \div 2.0-$ medium, $R_{S}=2.0 \div 2.6-$ high, and $R_{S}>2.6$ extremely high.

The fouling index shows a tendency to the sintering of deposits and if $F_{u} \leq 0.6-\quad$ low fouling inclination, $0.6<F_{u} \leq 40-$ high, and $F_{u}>40$ extremely high.

Calculations of slagging and fouling indices by the formulas (1-6) are shown in Table 2. As can be seen from the base-to-acid ratio, the fouling tendency of all of the ashes is medium. The chemical composition of the mineral part of sewage sludge indicates its slagging tendency. The sludge ash includes a high amount of iron and phosphorus, which leads to a decrease of the melting temperate of ash $[13,14]$. The values of $F_{u}$ and $R_{S}$ indicate that the studied ashes of not have a strong tendency towards the deposition process. It should be emphasized that sewage sludge ash contains a very low amount of sodium and potassium, which are the most aggressive elements of ash. The chlorine content is not high, too. Therefore, it can be assumed that during the combustion of sewage sludge it should not be found a lot of operating problems concerning the deposition of ash as well as corrosion risk should not be found, because of the low amount of potassium, sodium and chlorine in sewage sludge ash.

The crystalline mineral species in ash samples were identified by XRD and X-ray patterns are shown in Figure 2. A slight difference can be observed from the XRD patterns. It should be noted that only the main crystalline phases were observed by XRD in all of the samples. Since there were too little amounts of amorphous materials and crystalline phases, it was not possible to identify them. For all of the ashes, the main identified mineral phases are $\mathrm{Fe}_{2} \mathrm{O}_{3}, \mathrm{SiO}_{2}$ and $\mathrm{Ca}_{2,589} \mathrm{Mg}_{0,411}\left(\mathrm{PO}_{4}\right)_{2}$. The main crystalline phases are dominated by $\mathrm{P}, \mathrm{Si}, \mathrm{Ca}$ and $\mathrm{Mg}$ contents in ash, naturally occurring in sewage sludge. Silicates were not detected, although they would likely be generated in the reaction between $\mathrm{Al}_{2} \mathrm{O}_{3}, \mathrm{SiO}_{2}$, and $\mathrm{CaO}$. Silicon exists as quartz $\mathrm{SiO}_{2}$. Iron mineral compound is present only as hematite, $\mathrm{Fe}_{2} \mathrm{O}_{3}$. Iron oxide can react with quartz to form eutectics having low meting point temperatures, but they are from the amorphous phase and non-detective for XRD [16]. The most interesting is the phosphate of calcium and magnesium as a low-solubility mineral named whitlockite. The presence of whitlockite mineral in sewage sludge ashes was confirmed by $[17,18]$. Although the sewage sludge was oxy-combustion and the concentration of $\mathrm{CO}_{2}$ was higher than air combustion the carbonates are not detected. XRD analysis confirms the absence of phases which can cause corrosion e.g. the potassium or sodium phases.

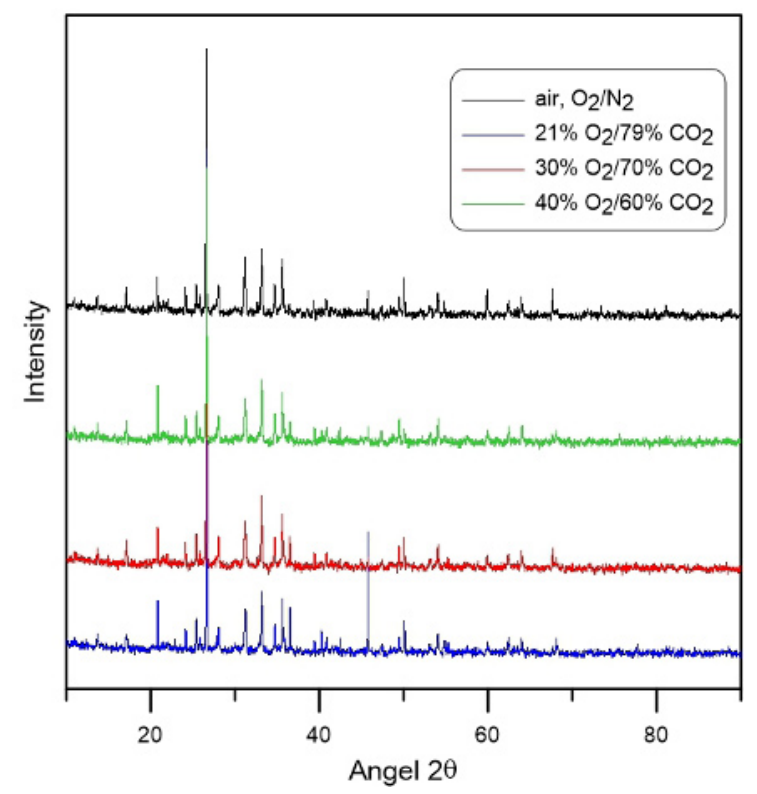

Figure 2. X-ray diffraction patterns of sewage sludge ashes obtained under different conditions.

Figure 3 presents the TG and DSC curves during heating the studied ashes under air atmosphere. TG corresponds to mass change and DSC reflects heat flow. The TGA analysis was conducted to study the thermal behaviour of sewage sludge ash. The slight differences 
in thermal behaviour have been observed for ash obtained under air atmosphere and oxy-combustion conditions. For Ash_1 a little mass gain from 100 to $900^{\circ} \mathrm{C}$ was observed. This could take place during the oxidation of an element of ash. Comparing the TG for A_2 to A_3 ashes, the influence of oxygen addition was not observed. For all of the ashes the thermal behaviour up to $1200^{\circ} \mathrm{C}$ can be divided into three steps. The first step concerns moisture release (up to $100^{\circ} \mathrm{C}$ ), which is absorbed on the ash surface during storage and preparation for investigations. The second step, between the temperature range of $120-900^{\circ} \mathrm{C}$ is without mass loss, and has a wide exothermic peak. The third stage, above $900^{\circ} \mathrm{C}$, corresponds to the decomposition of other compounds, probably due to phosphates and sulphates. The mass loss was not significant and was less than $4 \%$. It suggests the beginning of the melting process, but defined endothermic effects were not observed.

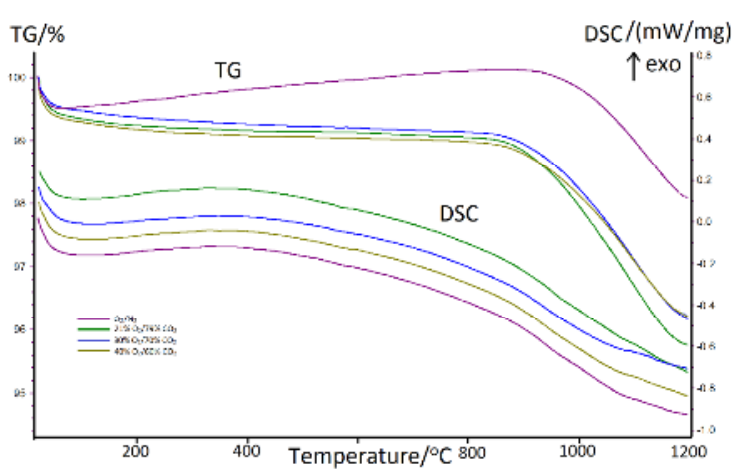

Figure 3. TG and DSC curves of sewage sludge ashes during the thermal process under air atmosphere.

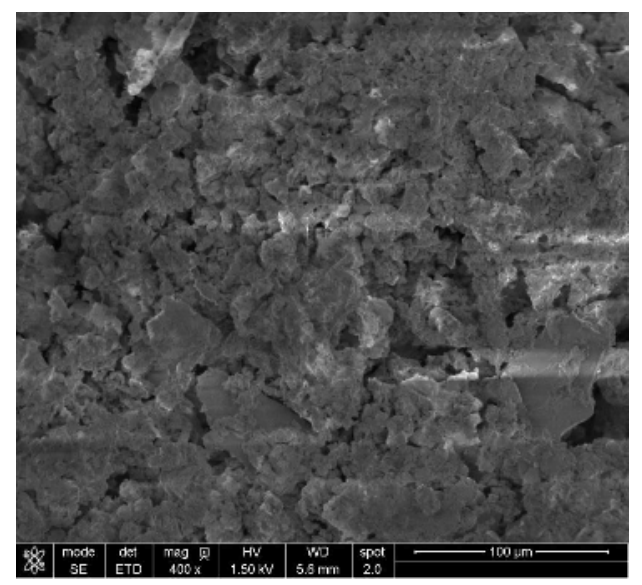

Figure 4. SEM images of sewage sludge ashes Ash_1.

The SEM method makes it possible to investigate the particle morphology and surface structure of ashes. ashes. Figures 4 and 5 present the morphology of the studied ashes. The particles of ash are different size and irregular. There are solid particles generated with smaller ones. Darker particles with white layers can also be identified. The particles of sewage sludge ashes seem to be angular with a sharp edge and a porous surface.

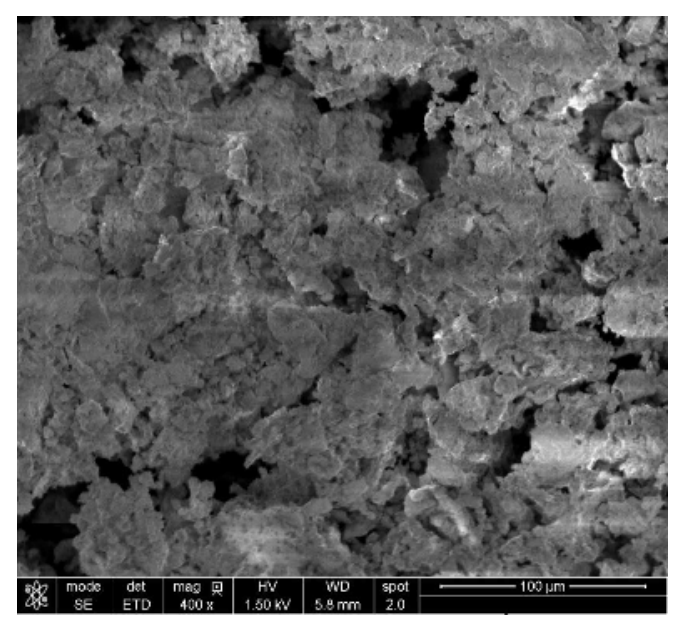

Figure 5. SEM images of sewage sludge ashes Ash_3.

\section{Conclusions}

This study presents a comprehensive analysis of sewage sludge ashes using analytical techniques such as XRF, XRD, SEM and TGA. The study was focused on getting information concerning whether the atmosphere of the combustion process influences the chemical composition of the ash. The obtained results indicate that there is only a very slight impact. It is difficult to confirm evident influence. Thus, the results show that sewage sludge can be successfully combusted in oxy-fuel technology. Generally, the ashes are dominant in the inorganic matter: $\mathrm{P}, \mathrm{Ca}, \mathrm{Si}$ and Fe. It was observed that the main mineral phases came from phosphorus and silicon and iron-based minerals. XRD analysis had confirmed the presence of the $\mathrm{Fe}_{2} \mathrm{O}_{3}, \mathrm{SiO}_{2}$ $\mathrm{Ca}_{2,589} \mathrm{Mg}_{0,411}\left(\mathrm{PO}_{4}\right)_{2}$ in a crystalline forms. The tendency of fouling and slagging calculated by chemical composition of the ashes in not very strong. Finally, the oxy-CFB combustion technology can be effectively used for sewage sludge thermal conversion processes.

\section{Acknowledgments}

The research leading to these results has received funding from the Polish-Norwegian Research Programme operated by the National Centre for Research and Development under the Norwegian Financial Mechanism 2009-2014 in the frame of Project Contract No Pol_Nor/208189/105/2015.

\section{References}

1. P. Manara, A. Zabaniotou, Renewable Sustainable Energy Rev. 16, 1081-1087 (2012)

2. A.I. Calvo, L.A.C. Tarelho, E.R. Teixeira, C. Alves, T. Nines, M. Duarte, E. Coz, D. Custodio, A. Castro, B. Artinano, R. Fraile, Fuel Process. Technol. 114, 58-68 (2013) 
3. A. Kijo-Kleczkowska, K. Środa, M. KosowskaGolachowska, T. Musiał, K. Wolski, Waste Manage. 46, 459-471 (2015)

4. A. Kijo-Kleczkowska, K. Środa, M. KosowskaGolachowska, T. Musiał, K. Wolski, Fuel 170, 141160 (2016).

5. A. Kijo-Kleczkowska, K. Środa, M. KosowskaGolachowska, T. Musiał, K. Wolski, Waste Manage. (to be published)

http://dx.doi.org/10.1016/j.wasman.2016.04.021

6. A. Magdziarz, S. Werle, Waste Manage. 34, 174179 (2014),

7. H.N. Jang, J.H. Kim, S.K. Back, J.H. Sung, H.M. Yoo, H.S.Choi, Y.C. Seo, Fuel 170 92-99 (2016)

8. M. Kosowska-Golachowska, A. Luckos, K. Klos, T. Musial, Proceedings of the 21st International Conference on Fluidized Bed Combustion, 611-618 (2012)

9. G. Garcia, J. Aruazo, A. Gonzalo, J.L. Sanchez, J. Abrego, Chem. Eng. J. 222 345-352 (2013)

10. V.K. Tyagi, S.L. Lo, Sust. Energ. Rev. 25 708-728 (2013)

11. A. Magdziarz, A.K. Dalai, J.A. Koziński, Fuel 176 135-145 (2016)

12. L. Weidong, L. Ming, L. Weifeng, L. Haifeng, Fuel 89 1566-1572 (2010)

13. M. Pronobis, Biomass Bioenergy 28 375-383 (2005).

14. M. Pronobis, Fuel 85 474-480(2006)

15. D. Vamvuka, D. Zografos, G. Alevizos, Bioresour. Technol. 99, 3534-3544 (2008)

16. L. Wang, G. Skjevrak, J.E. Hustad, M.G. Gronli, Fuel Process. Technol. 96 88-97 (2012)

17. M.B. Folgueras, M. Alonso, J.R. Folgueras, Fuel Process. Technol. 131, 348-355 (2015)

18. M. Atienza-Martinez, G. Gea, J. Arauzo, Sascha R.A. Kersten, A. Maarten J. Kootstra, Biomass Bioenergy, 65, 42-50 (2014) 